\title{
Religious Belief and Diaspora in Coetzee's Youth and Yassin-Kassab's The Road from Damascus
}

\author{
Ala’ Aldojan \\ English Literature, University of Jordan, Amman, Jordan \\ Yousef Awad \\ English Literature, University of Jordan, Amman, Jordan
}

\begin{abstract}
This study focuses on the role that faith plays in immigrants' lives in the South African novelist John Maxwell Coetzee's Youth (2002) and the Arab British author Robin Yassin-Kassab's The Road from Damascus (2008). Specifically, the study analyzes and scrutinizes the faith (lessness)-informed attitudes of the two protagonists toward the various challenges they encounter as diasporic subjects in a society that instills alienation and displacement. Each protagonist goes through an identity crisis triggered by his inability to reach his objectives and goals as Coetzee's John fails to be the poet he has aspired to be and Sami finds it hard to finish a PhD on Arabic poetry that his late father has encouraged him to pursue. While faith helps YassinKassab's protagonist to eventually overcome the challenges he faces, faithlessness in Coetzee's novel deepens the protagonist's sense of alienation and dislocation as the novel ends on a gloomy note. The study adopts an approach of textual analysis and comparison between the two novels. It also touches upon other fields including religion, history, identity, culture, diaspora, politics, and mental health. It examines the protagonists' cultural, national, and religious identities based on settling in diasporic communities in relation to the historical backgrounds and the socio-cultural conditions in the homeland and the host country.
\end{abstract}

Index Terms - diaspora, spirituality, religion, mental health, immigration

\section{INTRODUCTION}

This paper examines the influence of religious belief, or the lack of it, on the lives of immigrants in diaspora. It focuses on the role that religion crucially plays in the development and improvement of the protagonists' lives in diaspora in John Maxwell Coetzee's Youth (2002) and Robin Yassin-Kassab's The Road from Damascus (2008). We argue that developing spiritual stability based on religion represents immigrants' lifeline to survive in new and challenging environment, while its absence complicates their situations. The study adopts an approach of textual analysis and comparison between the two novels. Specifically, it focuses on the function of religious belief in overcoming the challenges that immigrants usually encounter as a result of displacement and alienation. Thus, religious faithfulness and faithlessness represent the ground on which the comparison between the two texts is held.

The experiences that the protagonists in Youth and The Road from Damascus undergo are quite comparable. Both John and Sami live in England as outsiders and they attempt to fit into London's social and cultural fabric. Academically, they aspire to fulfill their dreams in fields of arts and humanities; John aspires to be a poet, and Sami wishes to become an academic and a literary critic. In addition, they go through almost the same challenging stages on their ways to achieving their goals, including their impressions about their homelands, their interactions with women, their unstable religious and cultural identities, and, most importantly, encounters that challenge their self-perception and self-recognition. Despite all these commonalities, their stories end differently, mainly because of the role that faith plays in their lives.

In Coetzee's Youth, which is set in the sixties, readers meet young John, who aspires to leave South Africa and settle in Europe "for he will be an artist, that has long been settled" (Coetzee, 2002, p. 3). In London, John engages in many relationships with women; yet, he never meets the "exceptional girl" who "will appreciate what he is reading and recognize in him an exceptional spirit too" (Coetzee, 2002, p. 72). John believes that the exceptional girl will help him to become a poet. The novel presents the stages that John goes through while living in London until he meets Ganapathy with whom he shares the destiny of being foreigners, outsiders, and deserted in the West. Ganapathy's life ends miserably, and it foreshadows how John's life will end if he does not change his attitudes and behaviors.

Sami, Yassin-Kassab's protagonist, encounters challenges that his predecessor John has encountered in Britain. Yassin-Kassab's novel is set in the first decade of the twenty-first century. The novel traces the life of Sami, who arduously but unsuccessfully tries to finish his Ph.D. thesis on Arabic poetry. He believes that going to his homeland will enable him to start writing his thesis, but, ironically, this journey makes it more complex and confusing. Sami uncovers one of the family's direful secrets that would change his life's perspectives and beliefs later on. Once Sami returns to London, his self-exploration journey reaches its peak as he plummets in the world of drugs and sex. Just like 
John, Sami's relationships with women, including his wife Muntaha and his mother Nur, are tense and marked by continuous ideological clashes.

While Coetzee's novel ends gloomily, Yassin-Kassab's novel ends in a more positive mood, depicting Sami and his wife riding to his friend Tom Field's farm where the narrator informs us, Sami is "a bit more of a man now. Meaning, a moment of consciousness. Awe and dread. For now, that's all he can manage. Perhaps it's enough" (Yassin-Kassab, 2008, p. 349). The glimpse of hope that we can feel in Sami's journey is not found in John's; instead, Coetzee's novel ends unhappily as the omniscient narrator informs us that "when they [paramedics] have fetched Ganapathy they might as well come and fetch him [John] too" (Coetzee, 2002, p. 169). These words, to quote Katja Sarkowsky's words, show that "Youth ends on a note of utter despair: nothing, from John's viewpoint, has been accomplished and he might as well be dead" (Sarkowsky, 2019, p. 2059).

\section{RELIGIOUS BELIEF AND SPIRITUALITY}

In "The Four Domains Model: connecting Spirituality, Health and Well-Being," John Fisher (2011) demonstrates that defining the term spirituality and its relation to religiosity has been a paradoxical issue; as some scholars believe that spirituality is part of religion, while others assume that religiosity is "one dimension of spirituality" (p. 19). In "Religion and Well-being: the Mediating Role of Positive Virtues" Swati Sharma and Kamlesh Singh (2019) suggest that some academics associate spirituality with religion as it is "incorporated into religions" (p. 126). More accurately, Peter C. Hill and Kenneth I Pargament (2003) refer to spirituality as "the personal, subjective side of religious experience" (p. 64). Yet, other academics insist on excluding God and religion from spirituality (Fisher, 2011). Nevertheless, this study considers that spirituality and religiosity are connected as it aims at examining the spiritual perspective of the protagonists' lives and the effect of religious belief on their experiences in diaspora.

\section{Religious Belief, Optimism, AND Mental HeAlth}

Numerous studies have tackled the role of spirituality in healing the impacts of life struggles. Michael Galea (2014) explains:

How exactly spirituality works as a buffer is not clearly established. However, indications point at religious belief, rather than behavior, as being beneficial in providing a cognitive framework that might counter hopelessness [48]. Spirituality may ease the negative impact of trauma, by increasing affective wellbeing among individuals hurt somehow by a history of trauma. (p. 7)

The quotation above shows that religious belief relieves the hardships that a human being encounters. There is a soothing and comforting element that spirituality imparts on people.

According to Fisher (2011), spiritual wellbeing domains are: the personal, communal, environmental, and transcendental (p. 21). The personal domain is related to one self's values, purpose, and meaning of life (Fisher, 2011). It is more about the individual's "self-awareness" and "self-worth" as it includes feelings of "joy, fulfillment, peace, patience, freedom, humility, identity, integrity, creativity, intuition, self-worth" (Fisher, 2011, p. 23). Nevertheless, the communal domain focuses on "relationships, between self and others, relating to morality, culture and religion. These are expressed in love, forgiveness, trust, hope and faith in humanity" (Fisher, 2011, p. 22). The environmental domain extends the physical relationships with nature as it suggests "a sense of awe and wonder; for some, the notion of unity with the environment" (Fisher, 2011, p. 22). Finally, the transcendental domain involves "being: at one with Creator of the essence of the universe, in tune with God" (Fisher, 2011, p. 23). Fisher reveals the negative influence of the absence of any of these relationships on health. He asserts that "when relationships are not right, or are absent, we lack wholeness, or health; spiritual disease can grip our hearts" (Fisher, 2011, p. 23). Yet, he regards the transcendental domain as the ground on which, the other domains rely. Fisher (2011) asserts that "the relationship of a person with a Transcendent Other embraces relationships in the other three domains. For example, from a theistic point of view, a strong faith in God should enhance all the other relationships for SWB [Spiritual well-being]" (Fisher, 2011, p. 24).

Maryam Dilmaghani (2018) reveals the positive effect of religiosity and spirituality on individuals' mental health. Based on studies, she asserts that spirituality provides individuals with "meaning, optimism, and comfort" (p. 121-2). The novels present characters whose lack of connection to God result in their detached feelings from themselves. Consequently, their experiences in diaspora are marked with loss, misery, anguish, and despair. For instance, being detached from their inside, John and Sami rely on the environment and other individuals to reaching their goals in art. Furthermore, their lack of optimism leads them to develop pessimistic views on South Africa and Syria, respectively.

\section{Mother/ MotherLAND IN YouTH AND THE RoAD FROM DAMASCUS}

Christiane Brigitte Steckenbiller (2013) points out the role of one's personal experiences with a particular place in shaping the identity of that place. She suggests that "places are contingent, multi-layered, and do not have essential qualities. Nor does the membership, affiliation, or sense of belonging experienced in particular places come naturally" (Steckenbiller, 2013, p. 28). Specifically, individuals' reflections on their experiences in a particular place at a particular time identify that place. Steckenbiller (2013) implies that as long as "places can be safe or harmful, they can articulate inclusions and exclusions; they are embedded within complex relations of power;" thus, they "are not natural, 
passive, or pre-given" (p. 27). Correspondingly, Cara N. Cilano (2000) suggests that "a place's identity - formed by means of the activities that occur there, the various peoples living there, and its political and cultural past, present, and future" (p. 1). In other words, the formation of a place's identity associates the politico-cultural with the socio-cultural contexts during a specific time.

Thus, the identity formation of a place is a continuously changing process that relates the historical background of a place with the political, economic, cultural, and social conditions. Eventually, individuals form their own identities based mainly on what they experience and encounter in that place. Therefore, John and Sami present the identities of their motherlands based on their personal experiences within a particular historical context. Both novels open with the protagonists' encounters in their mothers/motherlands. In both novels, the protagonists speak about them in a derogative way. John and Sami refer to their mothers/motherlands as backward. Both are dissatisfied with their motherlands, and thus, they assume that London is the refuge where they can accomplish their dreams.

Indeed, John never belongs to South Africa. More accurately, he detests South Africa to the extent that "if a tidal wave were to sweep in from the Atlantic tomorrow and wash away the southern tip of the African continent, he will not shed a tear" (Coetzee, 2002, p. 62). He also suggests that "the Russians ought to invade South Africa without delay" (Coetzee, 2002, p. 100). More specifically, he seems detached from his homeland. Robert Kusek (2012) indicates that when the African workers' marches take place, "John remains relatively impervious to them" and he only thinks if "it can affect his plans of escaping South Africa" (Coetzee, 2002, p. 107). All he can think about at that time is the possibility of escape. Moreover, John is ashamed of his motherland. For example, when Astrid invites him to her house where he meets her English employer, he could hear her saying: "this is a European house, her eyes say: we don't need a graceless colonial here, and a Boer to boot" (Coetzee, 2002, p. 86). According to John, South Africa is "a colony that has always been more trouble than it has been worth. They [The British] would be content if South Africa would quietly vanish over the horizon" (Coetzee, 2002, p. 87). In addition, he dislikes Caroline who is "a girl from Cape Town," because she is "from a background as humdrum as his own" (Coetzee, 2002, p. 70). Furthermore, while working as a guard with Fino's nanny, Theodora, John expects that she resents him because of his South African origin. Therefore, he wants her to understand that he has quit South Africa forever (Coetzee, 2002).

Additionally, John refers to his homeland as backward. He regards growing up in such a country as the greatest obstacle to success. Since South Africa is "like an albatross around his neck" (Coetzee, 2002, p. 100), leaving it is his only choice to build a future. The narrator confirms that "South Africa was a bad start, a handicap. An undistinguished, rural family, bad schooling, the Afrikaans language: from each of these component handicaps he has, more or less, escaped" (Coetzee, 2002, p. 62). Lars Engle (2006) indicates that "John is certainly someone who "blames [his] environment for not living up to art and take[s] up residence in an art-world' or attempts to do so" (p. 43). Thus, leaving his motherland is a decision that he makes because "destiny would not come to him in South Africa, he told himself; she would come (come like a bride!) only in London or Paris or perhaps Vienna, because only in the great cities of Europe does destiny reside" (Coetzee, 2002, p. 165). John believes that he can master poetry only in Europe.

John's despise of his motherland is reflected in his relationship with his parents. He endeavours to be independent to avoid his parents. In other words, "he uses his independence to exclude his parents from his life" (Coetzee, 2002, p. 18). The narrator states that "he rarely sees his parents. Although they live only a short walk away, he does not visit" (Coetzee, 2002, p. 18). Moreover, he feels ashamed of the whole family. Thus, he never introduces them to any of his friends. The narrator comments that "he has never brought Paul to see them, or any of his other friends, to say nothing of Jacqueline" (Coetzee, 2002, p. 18). In consequence, his journey in becoming a poet in London is marked by the fact that "he is proving something: that each man is an island; that you don't need parents" (Coetzee, 2002, p. 3). John loathes his mother, her caring, and "her unchanging love for him" (Coetzee, 2002, p. 98). Each time he receives a letter from his mother, he wants her to "understand that when he departed Cape Town, he cut all bonds with the past" (Coetzee, 2002, p. 98). In addition to that, "though he does not particularly love himself" (Coetzee, 2002, p. 99), he does not accept her love. Despite the fact that she tries to help him while he lives alone, he resists her. He also keeps reminding himself that "he must harden his heart against her. Now is not the time to let down his guard" (Coetzee, 2002, p. 18). John never appreciates her though he envies Paul for having "a nice, normal relationship" (Coetzee, 2002, p. 18) with his mother. Despite his mother's attempts to provide him with genuine love, he never values her.

John's loathing of his motherland is also reflected in the way he endevours to distance himself from his father. For instance, along his journey in London, he seems determined to succeed not for himself; instead, his fear of becoming like his father was the driving force behind his efforts. The narrator informs us: "Giving up undertakings is his father's way. He is not going to be like his father" (Coetzee, 2002, p. 136), and "failing would be too much like his father" (Coetzee, 2002, p. 47). For instance, when he works as a guard after leaving IBM, he suspiciously asks himself: "is he after all going to turn out to be his father's son?" and "will he turn out to be a drunkard too" (Coetzee, 2002, p. 123). Dominic Head (2009) comments that the figure of the father has "little prominence or significance" because John's "determination to cast off the burden of his South Africa identity necessarily involves a rejection of parental values" (p. 10). He explains: "The brief mention of the father brings only the fear of an adverse genetic inheritance, "the strain of fecklessness"” (Head, 2009, p. 10).

Comparably, Sami despises Syria, its people, and their religion-culture traditions. According to Sami, Syria is marked with "supernaturalism" and "backwardness" (Yassin-Kassab, 2008, p. 2) due to women wearing the hijab. For 
instance, he assumes that people in Syria have no standards in treating each other well. Sami says that in "this cacophonous country: each individual playing from his own score, ignoring the others" (Yassin-Kassab, 2008, p. 2). Sami explains: "They don't respect each other" but "they fear the strong and despise the weak" (Yassin-Kassab, 2008, p. 2). Ironically, Sami expects to find a source of motivation in Syria to write his dissertation. The narrator comments "that his visit to Syria would crystallize his academic thoughts, that it was his talismanic last-chance cure, that the visit would produce what study and thought and time had failed to" (Yassin-Kassab, 2008, p. 44). Nevertheless, his visit to Syria deepens his sense of loss. The narrator confirms that Sami "returned to roots to find solutions;" yet, "the roots are shallow, and mythical" (Yassin-Kassab, 2008, p. 38). Thus, Syria as a homeland is a burden that he suffers from (Yassin-Kassab, 2008). Sami never feels belonging to Syria. For instance, he refers to Syria as "his father's country," hence; when he returns to England with "a yellowish smile spread over his face," he feels relaxed to be "home again" (Yassin-Kassab, 2008, p. 22). Going back to London, "his aim was to arrive in his own life as quickly as possible, his normal London life, to escape from that other life claiming him” (Yassin-Kassab, 2008, p. 22). In other words, Sami excludes Syria from his future, desired life. London represents his home.

Similar to John, Sami feels ashamed of his motherland and its religious identity. Sami never defines Syria as a Muslim country. For instance, when his teachers and the parents of his friends ask about Syria regarding it as a Muslim country, he answers: "It's a Mediterranean country" or "I don't have a clue" (Yassin-Kassab, 2008, p. 60). He believes that his Muslim origin is "nothing to be proud of" since "all origins except his had something going for them" (YassinKassab, 2008, p. 60). For Sami, Islam does not fit with London. He refers to religion as "an immigrant thing. [So,] It can't survive the cosmopolitan city" (Yassin-Kassab, 2008, p. 57). Moreover, he considers that "religion can't last much longer. It had developed in deserts and villages" (Yassin-Kassab, 2008, p. 57). Sami even could not find a present that looks like one from Syria in London because "London A to Z. None of it looked like presents from Syria" (YassinKassab, 2008, p. 23-4).

Sami's relationship with his mother is marked with ideological clashes. He rarely communicates with his mother since he blames her "for not loving his father enough" (Yassin-Kassab, 2008, p. 87) and for their unhappy marriage. Additionally, Sami accuses his mother, for abandoning his father, and wearing the hijab. For him, wearing the hijab is a betrayal of his father's secularism, yet "she'd let him grow up without telling him this essential piece of family information, about her brother [Faris]" (Yassin-Kassab, 2008, p: 9). Somewhat, he adopts the same reaction with Muntaha regarding covering her hair after he returns from Syria because she would look like his mother. Thus, Sami's relationship with both his mother and his wife is ideologically unsettling and is filled with tension until he uncovers the secret of his uncle Faris. Respectively, his perspective on them changes, especially, his mother whom he abandons for years.

For both John and Sami, London represents their refuge and home. In this context, Steckenbiller (2013) asserts that "memories are not confined to places of the past or places left behind but travel with the migrant and inform how he or she reacts to new contexts encountered on their journeys" (p. 21). Their experiences still exist inside. John and Sami expect that leaving their motherlands and abandoning their mothers will cut all ties with their motherlands, unexpectedly; everything flies with them to London. The protagonists' struggles with their own perceptions of their mothers and motherlands are connected. These perceptions are mostly marked with inner clashes, disgrace, and distress. As a result, they affect their lives in the host country negatively. While John could not escape the negative influence of his perceptions on his mother and motherland, Sami seems more accepting of everything about his homeland by the end of the novel. In other words, his relationship with his mother flourishes with the effect of religiosity or spirituality on his life.

\section{LOVE, WOMEN AND ART FROM JOHN's AND SAMI's PERSPECTIVES}

Fundamentally, love represents John's religion. The narrator indicates that "he may not believe in God but he does believe in love and the powers of love" (Coetzee, 2002, p. 3). John believes that finding the muse through passionate love would boost his skills in writing poetry. As a result, John develops "a constant faith that keeps him buoyant is that love will cure him" (Coetzee, 2002, p. 3). Relating love to art, this represents his orthodoxy, more specifically, his aims of life. The narrator declares, "only love and art are, in his opinion, worthy of giving oneself to without reserve" (Coetzee, 2002, p. 85). He expects women to transform him, or more, to transfigure him (Coetzee, 2002). As an artistto-be, John believes that "having mistress is part of an artist's life" since "art cannot be fed on deprivation alone, on longing, loneliness. There must be intimacy, passion, love as well" (Coetzee, 2002, p. 10). Correspondingly, he keeps wishing that "the beloved, the destined one, will see at once through the dull exterior he presents to the fire that burns within him" (Coetzee, 2002, p. 3). Thus, regardless of the complexities of his inner being, love will heal everything.

Despite the fact that John yearns for love relationships, he never builds a healthy, successful romantic relationship. In other words, none of them empowers his writing skills and talent as a poet. Instead, they deepen his sense of hopelessness. Kusek (2012) comments that "his affairs are numerous, yet unsatisfactory and not even once does a relationship bring him closer to the emotional fulfilment which he so desperately desires" (Coetzee, 2002, p. 108). Additionally, Mary Dooley (2003) argues that John "manages to find sexual partners but no lasting satisfaction, and he treats the women coldly and insincerely, finding none of them measure up to his hopes of being initiated in the 'element force of the universe"” (p. 76). Kusek (2012) explains that John longs for relationships, "however, when confronted 
with the real problems concerning a relationship, he behaves disgracefully" (p. 107). Therefore, instead of deeds, he thrives on wishes regarding love. Since John never attempts to do anything toward the challenges in his relationships, he fails as a lover. The narrator confirms that "he is not a good enough lover, not fiery enough, not passionate" (Coetzee, 2002, p. 32).

Galea (2014) explores the relationship between spiritual wellbeing and emotional stability. He indicates that "a healthy spirituality is a resource and is highly correlated to emotional wellbeing" (p. 7). Further, Malinakova et al. (2020) suggest that "criteria for attachment relationships" is approximately linked to individuals" "perceived relationship with God" (p. 2). Malinakova et al. (2020) add numerous studies to prove "that religious instability may have similar roots as those of unstable emotional attachment" (p. 2). Due to that, John is emotionally damaged. More accurately, his lack of spirituality results in struggles in his intimate relationships. Moreover, John's failure as a lover is associated with his failure as an artist. The omniscient narrator states: "He is well aware that his failure as a writer and his failure as a lover are so closely parallel that they might as well be the same thing" (Coetzee, 2002, p. 166). In this view, these fragile relationships with women fail to improve his poetry skills.

Similar to John, Sami believes that it is his destiny to be involved in poetry as his Arab features "made him dream of his destiny. Of poetry" and it represents "the second element of" his identity (Yassin-Kassab, 2008, p. 14). Following his father's steps, Sami aspires to write books about Arabic poetry. As John's lack of religiosity complicates his relationships with women, respectively, Sami develops a confusing relationship with his mother and his wife because of their religiosity. Sami and Muntaha's relationship proceeds smoothly since their first meeting. However, things change once she decides to wear the hijab. Awad and Dubbati (2018) comment that "after Sami returns to his home in London, he is shocked to find out that his wife, Muntaha, has decided to wear a hijab/headscarf, reminding Sami of his mother, who made a similar choice years ago, despite the relentless objections of Sami's father" (Yassin-Kassab, 2008, p. 2). Sami's projection of her hijab is built on other people's perceptions of him as the son of the secularist professor, Traifi. Sami comments: “'What will people think of me? They'll think I make you wear it"” (Yassin-Kassab, 2008, p. 100).

Like John, Sami relates the success in art to love. Relatively, both love and getting his $\mathrm{PhD}$ in art are Sami's ultimate fulfillment. Sami feels revived once he meets Muntaha and starts working on his PhD:

This little Sami felt to the adult Sami like his dead, innocent child, buried in the blind years. Everything since that particular funeral, since adulthood, had been enveloped in an anticlimactic fog of mourning. Except for meeting Muntaha. Except for beginning his $\mathrm{PhD}$. There had been hope until then. It was the start of the PhD that marked the transition. (Yassin-Kassab, 2008, p. 33)

Working on his PhD is something that Sami connects to his father's soul. Awad and Dubbati remarks: "attempting to fulfill his father's wishes and emulate his academic success, Sami is determined to write a dissertation that diminishes the influence of Islam on Arab cultural productions" (Yassin-Kassab, 2008, p. 2). Also, it represents his wish to pay back the debt; this is the dream that he longs to achieve.

\section{JOHN'S AND SAMI's SELF-PROBING JOURNEYS}

Fisher (2011) reveals that spirituality creates a good understanding of the inner self and the surrounding. He suggests that "spirituality is concerned with a person's awareness of the existence and experience of inner feelings and beliefs" (p. 20). And according to that, this provides individuals with "purpose, meaning and value to life" (Fisher, 2011, p: 20). John's lack of spirituality prevents him from understanding himself and his choices in life. The narrator states that "he does not know what he believes. Sometimes he thinks he does not believe anything" (Coetzee, 2002, p. 10). His inability to understand himself makes him appear as a mystery to others, a mystery that, for him, "feels like a sickness, a moral sickness: meanness, poverty of spirit, no different in its essence from his coldness with women" (Coetzee, 2002, p. 95). Thus, he cannot express himself; being invited by the Indian family, John never expresses his gratitude for their kindness and generosity; instead, he distances himself from them and never invites them back.

Accordingly, he pretends to be and acts like things he does not have or feel. Reflecting on his relationship with Jacqueline, he claims that going to the beach that "unresisting he follows, does his best, goes through with the act, even pretends at the last to be carried away. In fact he is not carried away" (Coetzee, 2002, p. 5). Similarly, when Astrid stays at his house, "he pretends to like having her there, but the truth is he does not" (p. 87). Further, when Ganapathy asks him to think about fellowships in America, he promises that "I'll think about it," yet "he has no intention of thinking about it" (Coetzee, 2002, p. 152). John is detached from his inside, thus, he has no real enthusiasm and passion towards anything. Specifically, he is not solid about his choices in life, and accordingly, "solidity is what he has always lacked" (Coetzee, 2002, p. 44). For instance, he knows that "he has to sit down and write, that is the only way. However, he cannot begin writing until the moment is right" (Coetzee, 2002, p. 166). The narrator comments that "no matter how scrupulously he prepares himself, wiping the table clean, positioning the lamp, ruling a margin down the side of the blank page, sitting with his eyes shut, emptying his mind in readiness," yet the right moment never comes (Coetzee, 2002, p. 166).

Dilmaghani (2018) affirms that many studies proclaim the positive effect of religiosity and spirituality on mental health as they furnish religious or spiritual individuals with comfort and optimism (p. 121-2). John's lack of spirituality averts him from appreciating the positive and bright side of his life. For instance, though London offers him jobs and a chance to develop himself as a computer programmer, he never sees that: 
He is in England, in London; he has a job, a proper job, better than mere teaching, for which he is being paid a salary. He has escaped South Africa. Everything is going well, he has attained his first goal, he ought to be happy. In fact, as the weeks pass, he finds himself more and more miserable. He has attacks of panic, which he beats off with difficulty. In the office there is nothing to reset the eye on but flat metal surfaces. (Coetzee, 2002, p. 47)

The quotation above shows John's inability of appreciating the blessings of his life. John never appreciates his job at IBM as a computer programmer in London at a young age: "a twenty-four-year-old computer programmer in a world in which there are no thirty-year-old computer programmers" (Coetzee, 2002, p. 168). Instead, John quits his job for no reason.

John's faithless self fails to face the challenges of the new environment. Emeka Chukwumezie (2014) proclaims that as a diasporic subject, "alienation in this sense becomes part of man's consciousness in his existence in the world, for when man can no longer determine the direction of his labour; the quantity and value of his product, he is seen as lost in that context" (p. 10). In the diasporic context of London, John leads a life of nihilism, depression, alienation and detachment. For example, he cannot see any possible good opportunity in his future. So, when he is asked to renew the work permit in the UK, he thinks of what could happen if he goes back to South Africa and the possibility of getting a scholarship as "he is too old by now for scholarships he would be competing against younger students with better records" (Coetzee, 2002, p. 140).

Similar to John, Sami's disregard of his inside leads him to a phase of loss. Disappointed by discovery of his uncle Faris's gruesome story in Syria, Sami, as Awad and Dubbati (2018) point out, is "deeply disappointed and disillusioned, [... and] indulges in a world of sex, drugs, and alcohol" (p. 2). He begins to collapse, falling prey to a "chain-smoking, junk-guzzling, substance-abusing world. A sweating world, whose temperature control was hopelessly disabled" (Yassin-Kassab, 2008, p. 175). He wanders aimlessly in the streets of London, growing a beard, and he stops washing up. Eventually, bearded Sami is arrested near a mosque and is assumed to be a terrorist. The beard signifies an Islamic background; yet, as the police note "Sami Traifi. The real one. He doesn't have a beard. He takes drugs, drinks alcohol" (Yassin-Kassab, 2008, p. 334). This loss of self expands to involve his academic dream.

Awad and Dubbati (2018) comment: "Sami finds himself further pushed to the edge when his academic supervisor informs him that his research topic is not viable, reminding him of his obligation, as the son of a renowned thinker, to produce a first class dissertation" (p. 2). Despite his supervisor's support for him with ideas and chances to write his dissertation on Arabism and poetry for the sake of his father, it makes him "a man unsettled, out of place, unexplained" (Yassin-Kassab, 2008, p. 35). He feels that there is "a core of truth and direction nearly visible yet decisively hidden" and "out of reach" as a result of "his lack of clear sight" (Yassin-Kassab, 2008, p. 35). Correspondingly, Sami accomplishes nothing and starts to detest himself as his life decays:

That he had betrayed everybody, in various ways. Mustafa. Marwan. His mother, of course. Now Muntaha. Not just now, but for a decade. He'd let down Mustafa by failing as an academic, even as an atheist. For Marwan, the betrayal was not being a Muslim, or a father. For his mother, he was not a son. For his wife, not a man. The pattern of his relations with the world was to betray its trust. Everybody's trust. (Yassin-Kassab, 2008, p. 201)

Despite the fact that he disappoints all people in his life, the feeling of this failure frees him from the limitations created by his dependency on his father. Hence, "after all that loss, he felt bright and free" (Yassin-Kassab, 2008, p. 192). For example, when New York's World Trade Center attack happens, as the narrator notes, Sami "has no scale to measure the event. Nothing inherited from Mustafa. No nationalist way of judging. No Qabbani verse to help him. Here was life imitating disaster movies, more or less. But where was the hero?" (Yassin-Kassab, 2008, p. 314-5).

Eventually, for Sami, "the world means nothing" (Yassin-Kassab, 2008, p. 221). The narrator maintains that "it was easy for Sami, in his new father-free state, to agree. The stars are merely rock and fire. Nations are dreams, or perhaps nightmares. None of it has any importance" (Yassin-Kassab, 2008, p. 221). Indeed, this presents Sami's first spiritual encounter. In "The Origin and Evolution of Sufism," Khanam (2011) states that "the most characteristic aspect of the life of the early Sufis was their desire for noninvolvement in the matters of the world" (p. 9). Sami lets go of all inherited, worldly assumptions. Thus, he recognizes the "failure of nation as home" (Qutait, 2018, p. 76). Accurately, it is a rebirth for Sami; everything seems naked and bare.

Consequently, his "self-exploration" journey leads him to "take a critical decision" (Awad and Dubbati, 2018, p. 7). He is guided by the fact that "the loss of this inherited set of political ideals leads him to search for alternative forms of belonging, as Sami begins to contrast his own identity struggles with the paths taken by others around him" (Qutait, 2018, p. 75). As a result, "Sami envied his brother-in-law's capacity for self-definition" that he has an opinion about the attack (Yassin-Kassab, 2008, p: 218). Sami needs to redefine himself away from his father: "[N]othing was left of Mustafa Traifi, it was time to admit that. Time to stop behaving as if his father was still here. And time, therefore, to examine all the superstitions he'd built around his father's ghost" (Yassin-Kassab, 2008, p. 183). At this stage of Sami's life, the novel demonstrates "the importance of the ability to change, to reject wholly what was previously believed, as a necessary condition to imagine alternative modes of belonging" (Qutait, 2018, p. 83). He needs to fuel his soul to continue his journey and reshape his perceptions of the world, consequently, reaching a state of satisfaction and happiness. 


\section{JOHN's SPIRITUALITY}

John is spiritually trapped. For him, spirituality is connected to misery. The narrator declares that John believes that "misery is a school for the soul" (Coetzee, 2002, p. 65). Additionally, as an artist-to-be, John relates the creation of art to suffering and misery. Therefore, he maintains his own suffering, believing that it is necessary to suffer in order to evolve. The narrator adds: "his sole talent is for misery, dull, honest misery. If this city offers no reward for misery, what is he doing here?" (Coetzee, 2002, p. 97):

Even as he plods around the cold streets of this alien city, heading nowhere, just walking to tire himself out, so that when he gets back to his room he will at least be able to sleep, he does not sense within himself the slightest disposition to crack under the weight of misery. Misery is his element. (Coetzee, 2002, p. 65)

John lacks spirituality. Fisher (2011) suggests that the level of the spiritual health of an individual can be measured to be low or high, yet "if it is static, there is neither growth nor development, nor spiritual life. The spiritual quest is like being on a journey: If you think you've arrived, you haven't yet begun, or you are dead" (p. 20). Seen from his perspective, John's pessimism prevents him from enjoying the little things in his life. For instance, paintings at Tate Gallery seem meaningless as "the painting means nothing to him" (Coetzee, 2002, p. 92); he is dead inside. John is unable to appreciate a painting. Additionally, many of his days are marked "with an S in his diary: days of silence" (Coetzee, 2002, p. 114).

Yet it is John's choice to abandon religion. For instance, he criticizes the article in the Observer that refers to the angst in the European cinema to "a fear of nuclear annihilation; also from uncertainty following the death of God" (Coetzee, 2002, p. 46). He regards "the death of God" as "a failure on God's part" accusing God for the depression and uncertainty following the death of God (Coetzee, 2002, p. 49). While John acclaims writers whose works mainly diminish religion including, Ezra Pound and Samuel Beckett, he disapproves writers whose works address religion including Shakespeare, Chaucer, and Hopkins. In "Finitizing Life: Between Reason and Religion in JM Coetzee's Jesus Novels," Farrant (2019) asserts the fact that "Coetzee rejects the sovereignty of both reason and religion by depicting characters open to their inevitable riskiness of passionate life" (p. 178). John follows his desired passions in fulfilling his dream away from reason, religion, family and homeland. In "The Disasters of Youth: Coetzee and Geomodernism," Sheehan (2011) suggests that Youth is "a study in denial, John finally ends up denying the very thing that set him on his way: the modernist quest for self-transformation through art and experience. [. . .] Youth is a thorough dismantling of the modernist myth" (p. 28-9). What he relies on apart from religion, including the setting, women, and other artists fail him. In "How to 'rise above mere nationality': Coetzee's Novels Youth and Slow Man in the World Republic of Letters," Vold (2011) implies that "as his initial plan of becoming a successful metropolitan writer is not working, and the social and individual progress of his bildung [a German word for self-cultivation] is not bearing fruit" (p. 40). John ignores religion.

Additionally, watching the biblical drama film "Gospel According to St Mathew," John sheds a stream of tears as the scenes deeply affect him though "after five years of Catholic schooling he had though he was forever beyond the appeal of the Christian message. But he is not" (Coetzee, 2002, p. 154). Yet, this never leads him to think of religion as an influence in his life. He watches the scene of the angel announcing Jesus resurrection "and the common folk of the land, the halt and the maimed, the despised and rejected, come running or hobbling, their faces alight with joy, to share in the good news, his own heart wants to burst; tears of an exultation he does not understand stream down his cheeks" (Coetzee, 2002, p. 154). He reflects nothing on the tears and all he thinks about is to be back to his routine again and the "tears that he has surreptitiously to wipe away before he can emerge into the world again" (Coetzee, 2002, p. 154). John loses the opportunity to re-emerge through religion.

John's lack of religion deepens his sense of alienation and hinders him from overcoming the challenges he faces in diaspora. Dilmaghani (2018) suggests that "non-religious individuals seem likely to suffer in terms of the social support stemming from religious attendance" (p. 121). Consequently, having no one to guide him to the path of spirituality and faithfulness, John is trapped in limbo and his life is devoid of any religious belief that may give him answers for some urgent ontological and existential questions. Consequently, the dark ending of the novel represents John's last chance to look inside rather than outside and to reinforce his spiritual life.

\section{THE SPIRITUAL SAMI}

In "One Religion, Two Tales: Religion and Happiness in Urban and Rural Areas of China," Zhang et al. (2019) assert the role of religiosity in creating happiness and emotional fulfillment. They demonstrate that happiness is measured by the individual's valuing of his/her emotive, mental and intellectual life which is driven by two factors: subjective ones, including religion, and objective ones, involving physical matters: "Thus, religion influences religious peoples' subjective responses to objective factors" (Zhang et al., 2019, p. 3). Zhang et al. (2019) maintain that "religious belief" increases individuals' happiness due to the meaningful interpretations it provides religious people with, which enable them to understand life events and the purposefulness of life (p. 3). Sami, at this stage of his life, lacks religiosity; yet, Muntaha's adequate understanding of Islam and her connection to God lead Sami to better understand life.

Muntaha's guidance awakens Sami's soul. It represents the power that rejuvenates him. So, addressing Sami after his collapse with "'habibi' was encouraging” (Yassin-Kassab, 2008, p. 312) that he goes to her and visits his mother on her 
request (Yassin-Kassab, 2008, p. 321). Therefore, his visit to his mother makes things clear to him regarding his uncle Faris and the suffering he goes through because of his fathers' nationalist ideals. Additionally, Muntaha teaches him to question things before admitting to them. For example, she comments on the 11/9 attack: "you can't take anything for granted. Not a woman, nor an idea. Not a political situation. Not life or death. Nothing is simple. Everything is always changing, and always - if you pay enough attention - surprisingly" (Yassin-Kassab, 2008, p. 323).

At this stage, Sami connects to God and builds a connection with Him with no previous assumptions imposed by his father. Sami's spiritual quest is enriched as he addresses God face to face (Khanam, 2011, p. 8). The narrator informs us that "Sami the soul doesn't exist, nor does God. If he's going to believe in himself, he may as well believe in God. It seems only fair. Sami and God appear to be, in some sense, brothers" (Yassin-Kassab, 2008, p. 246). Khanam (2011) indicates that "for Sufis, connecting to God is about losing oneself in God" (p. 7). Sami is in tune with God. Therefore, "Sami nodded at the miracle of sight. He no longer experienced body-claustrophobia, but something like its opposite, a sense of openness and space. Now he claimed a doctrine of radical unknowing, and the beginning of acceptance" (Yassin-Kassab, 2008, p. 347). This acceptance precedes a state of believing; the belief that enables him to free himself from the bounds and limits of the doctrine of his father. Consequently, he begins to transform since "everything [is] gobbling everything else, relentlessly teaching a very simple lesson: of the power of change" (Yassin-Kassab, 2008, p. 348). Sami changes:

Sami had developed a trembling, contingent faith, not necessarily expansive enough to house an eternal heaven, certainly not for Sami as he is. For what is he, now? Not much any more. Not Mustafa's son, nor Marwan's son-in-law. Not the child of corpse dust. Not an academic. Not a member of the eternal Arab nation ... He's Nur's son. Muntaha's husband. (Yassin-Kassab, 2008, p. 348)

The quotation above asserts that Sami's journey takes a new twist, a point that challenges all his previous conceptions and beliefs. Eventually, Muntaha and Nur's guidance awakens his soul.

Specifically, both Muntaha and Nur lead him to a stage of acceptance, tranquility, and peace. Qutait (2018) suggests that Sami is defined by his wife and his mother (p. 82). Specifically, there is "a shift from his father's nationalist narrative of 'Qabbani' to his mother's alternative narrative of 'Qur'an"” (Qutait, 2018, p. 79). Therefore, "as Sami's perception of Islam changes once he frees himself from the specter of the father; the hijab like the beard he decides to grow, transforms in ideological significance into a visible declaration of identity in Britain" (Awad and Dubbati, 2018, p. 9). Sami as well resolves that "Islam is something you find inside yourself rather than in any specific country" (Yassin-Kassab, 2008, p. 221). Sami feels a new sense of belonging apart from national ideals.

\section{Religious Belief AND HEALing}

Galea (2014) examines the effect of religiosity on traumatic experiences. He argues that studies show that spirituality enhances health due to the salutary outcomes related to it in decreasing disorderliness (Galea, 2014). More accurately, spirituality eases the negative effects of trauma by enhancing the individual's wellbeing (Galea, 2014). Furthermore, "[r]esults clearly indicate that faith maturity related positively with wellbeing, positive affect, personality and posttraumatic growth, thus suggesting that it relates well with important life events" (Galea, 2014, p. 5). Thereupon, finding inner peace created by spirituality helps "trauma victims" adhere to "a more refined and personal spiritual journey, one that could enhance their healing” (Galea, 2014, p. 7). Sami's discovery of his father's betrayal of his uncle Faris is a traumatic experience. For Sami, it represents a shock as it contradicts the romanticized image that he beholds for his father since his childhood. Consequently, Qutait (2018) implies that "Sami begins seeking the coherent answers provided by religious ideology as a replacement to his father's pan-Arab narrative" (p. 79), which marks the start of his self-exploration journey. Awad and Dubbati (2018) summarize this journey, stating that "Sami's quest leads him to reevaluate his father's antagonistic thoughts about Islam and reflect on his own beliefs and exigencies, eventually becoming a practicing devout Muslim" (p. 6). Qutait (2018) argues that "Yassin-Kassab explores the role of religion in establishing a sense of connection to the past and to the homeland and dramatizes the Islamist appropriation of national causes" (p. 79). Religion is what transforms and uplifts Sami from the abyss.

By the same token, Fisher (2011) reveals the positive influence of spirituality on providing individuals with peace. He maintains that "spirituality helps individuals to live at peace with themselves, to love (God and) their neighbor, and to live in harmony with the environment" (p. 20). At this stage, Sami develops a sense of belonging to his close circle of family members and friends. Sharma and Singh present the fact that succession of studies examine the relationship between religiosity and wellbeing. The studies prove that as individuals share religious beliefs, they develop a sense of belonging (Sharma and Singh, 2019). For example, Sami joins Ammar and Mujahid to pray Asr. He feels that he belongs to a group when he is called "brother": "Brother, they called him. They were willing to make him their brother" (Yassin-Kassab, 2008, p. 224). As for Muntaha, Sami reconnects with the world and with nature at Tom Field's farm, and they pray together "at lunchtime and in the middle afternoon. Out in nature, prayers felt easy to Sami. Out in nature, marvelling in" (Yassin-Kassab, 2008, p. 347). As "the real value of spirituality from a functional psychological standpoint may well be its ability to enhance human flourishing" (Galea, 2014, p. 7), spirituality seems to be an essence in establishing psychological wellbeing. Consequently, simple activities with Muntaha enrich the stability of his mental health as "in another long dusk they washed with dust, prayed, nibbled sandwiches, held hands" (Yassin-Kassab, 2008, p. 348). 
Sharma and Singh (2019) suggest "that religiosity indirectly influences well-being through two different pathways: One is via the mediators of spirituality, gratitude and altruism and the other is via mediators of spirituality, gratitude and forgiveness" (p. 122). In addition, Zhang et al. (2019) assert that "by emphasizing non-material aspects of life, religion may help to improve happiness by providing stress coping skills, as well as by providing a strong sense of purpose and acceptance over and above one's economic conditions or social status" (p. 2). Accordingly, Sami reaches a mental and psychological balance. He is aligned with his soul. Sami is in harmony with his inside. Respectively, unlike John's journey, there is a glimpse of hope in Sami's journey through Muntaha's faith-informed guidance and with the support Sami gains from his mother and friend, Field. At the end of the novel, Sami sincerely connects to his true self, nature around him, and his family members. More accurately, the presence of religious faith reshapes Sami's vision of life and provides him the haven where he is aligned with his within and his surroundings.

\section{CONClusion}

Both Coetzee's Youth and Yassin-Kassab's The Road from Damascus consolidate alienated diasporic subjects who aspire to fulfil their dreams in the field of art in the same host country. They go through comparably similar socially, psychologically, and mentally challenging phases. In addition, they develop identical impressions about their homelands, their mothers, and other women in their lives. The loathing that John feels toward his homeland parallels the hatred that Sami harbors for his motherland. Moreover, both have unhealthy relationships with their mothers, and with the women they meet in their lives. The complex relations they develop with friends, women, and family members, and their aspirations to excel in the world of poetry further complicate their daily experiences in diaspora. Despite the fact that these protagonists go through almost the same confusing and challenging stages that lead to the same selfexploration and self-recognition journeys, their stories end differently. While Sami appears to be rejuvenated and aligned with life through Muntaha's faith-informed guidance, John's lack of faith renders him psychologically, socially, and even mentally vulnerable and lost in the diasporic context of London.

\section{REFERENCES}

[1] Awad, Yousef and Dubbati, Barkuzar. (2018). Hamlet's Road from Damascus: Potent Fathers, Slain Ghosts and Rejuvenated Sons. Borrowers and Lenders: The Journal of Shakespeare and Appropriation, 11: 1-20.

[2] Awad, Yousef. (2012). The Arab Atlantic: Resistance, Diaspora, and Trans-cultural Dialogue in the Works of Arab British and Arab American Women Writers. U.K.: Lambert Academic Publication.

[3] Chambers, Claire. (2012). Sexy Identity-Assertion: Choosing Between Sacred and Secular Identities in Robin Yassin-Kassab's The Road from Damascus. In: Ahmed, Rehana and Morey, Peter and Yaqin, Amina (Ed), Culture, Diaspora, and Modernity in Muslim Writing. (pp. 117-131), New York, Routledge.

[4] Chukwumezie, Emeka. (2014). Alienation, Identity Crisis and Racial Memory: The Realities of Blacks in Diaspora in Andrea Levy's Fruit of the Lemon. International Journal of Linguistics and Literature, 3 (1), 9-18.

[5] Cilano, Cara N. (2000). Place-ing Postcolonial Identity in Contemporary Literature by Women. Doctoral Dissertation, Duquesne University, Pennsylvania.

[6] Clifford, James. (2015). Diasporas. Cultural Anthropology, 9 (3), 302-338.

[7] Coetzee, John M. (2002). Youth, (1st ed.). Great Britain: Vintage.

[8] Dilmaghani, Maryam. (2018). Importance of Religion or Spirituality and Mental Health in Canada. Journal of Religion and Health, 57 (1), 120-135.

[9] Dooley, Gillian Mary. (2003). Alien and adrift: the diasporic sensibility in V. S Naipaul's Half a Life and J. M Coetzee's Youth. New Literatures Review, (40), 73-82.

[10] Engle, Lars. (2006). Being Literary in the Wrong Way, Time, and Place: JM Coetzee's Youth. English Studies in Africa, 49 (2), 29-49.

[11] Farrant, Marc. (2019). Finitizing Life: Between Reason and Religion in JM Coetzee's Jesus Novels. Journal of Modern Literature, 42 (4), 165-182.

[12] Fisher, John. (2011). The Four Domains Model: Connecting Spirituality, Health and Well-Being. Religions, 2 (1), 17-28.

[13] Galea, Michael. (2014). The relationship of personality, spirituality and posttraumatic growth to subjective wellbeing. Open Access Library Journal, 1 (8), 1-10.

[14] Head, Dominic. (2009). The Cambridge Introduction to JM Coetzee. (1st ed.), U.K.: Cambridge University Press.

[15] Hill, Peter C. and Pargament, Kenneth I. (2003). Advances in the conceptualization and measurement of religion and spirituality: Implications for physical and mental health research. American psychologist, 58 (1), 64-74.

[16] Kämmerle, Monika and Unterrainera, Human-Friedrich and Dahmen-Wassenberga, Phoebe and Fink, Andreas and Kapfhammer, Hans-Peter. (2014). Dimensions of Religious/Spiritual Well-Being and the Dark Triad of Personality. Psychopathology, 47 (5), 297-302.

[17] Khanam, Farida. (2011). The Origin and Evolution of Sufism. Al-Idah, 22 (1), 1-10.

[18] Kusek, Robert. (2012). Writing Oneself, Writing the Other: JM Coetzee's Fictional Autobiography in Boyhood, Youth and Summertime. Werkwinkel, 7 (1), 97-116.

[19] Lenta, Margaret. (2003). Autrebiography: JM Coetzee's Boyhood and Youth, English in Africa, 30 (1), 157-169.

[20] Malinakova, Klara and Tavel, Peter and Meier, Zdenek and van Dijk, Jitse P. and Reijneveld, Sijmen A. (2020). Religiosity and Mental Health: A Contribution to Understanding the Heterogeneity of Research Findings. International Journal of Environmental Research and Public Health, 17 (494), 1-11.

[21] Parssinen, Keija. (2020). Writing as Spiritual Offering. World Literature Today, 94 (1), 26-29. 
[22] Qutait, Tasnim. (2018). "Qabbani versus Qur'an”: Arabism and the Umma in Robin Yassin-Kassab's The Road from Damascus. Open Cultural Studies, 2 (1), 73-83.

[23] Rashid, Catherine. (2012). Cultural Translation and the Musafir: a Conversation with Robin Yassin-Kassab. Crossings: Journal of Migration \& Culture, 3 (1), 151-162.

[24] Rashid, C. E. (2012). British Islam and the Novel of Transformation: Robin Yassin-Kassab's The Road from Damascus. Journal of Postcolonial Writing, 48 (1), 92-103.

[25] Sarkowsky, Katja. (2019). J. M. Coetzee: Boyhood (1997) and Youth (2002). In: Wagner-Egelhaaf, Martina (Ed), Handbook of Autobiography/Autofiction. (pp. 2049-2063), Germany, De Gruyter.

[26] Sharma, Swati and Singh, Kamlesh. (2019). Religion and Well-being: the Mediating Role of Positive Virtues. Journal of Religion and Health, 58 (1), 119-131.

[27] Sheehan, Paul. (2011). The Disasters of Youth: Coetzee and Geomodernism. Twentieth Century Literature, 57 (1), $20-33$.

[28] Steckenbiller, Christiane Brigitte. (2013). Putting Place Back into Displacement: Reevaluating Diaspora in the Contemporary Literature of Migration. Doctoral Dissertation, University of South Carolina, Columbia.

[29] Vold, Tonje. (2011). How to rise above mere nationality: Coetzee's Novels Youth and Slow Man in the World Republic of Letters. Twentieth Century Literature, 57 (1), 34-53.

[30] Yassin-Kassab, Robin. (2008). The Road from Damascus, (1st ed.). U.K.: Penguin.

[31] Zhang, Jing Hua and Chi Zo, Wen and Jiang, Xiao Jiang. (2019). One Religion, Two Tales: Religion and Happiness in Urban and Rural Areas of China. Religions, 10 (532), 1-16.

Ala' Aldojan is a recent postgraduate from the University of Jordan. She has completed B.A. and M.A. in English literature from the University of Jordan. She also has a diploma in teaching English as a second language from the University of Jordan. She currently works as an English teacher at the Ministry of Education in Jordan. Her research interests include various aspects of comparative literature, diaspora studies, and spirituality.

Yousef Awad is a professor of contemporary Arab diasporic literature at the University of Jordan. His first monograph, The Arab Atlantic: Resistance, Diaspora, and Trans-cultural Dialogue in the Works of Arab British and Arab American Women Writers, is based on his PhD thesis which he completed in 2011 at the University of Manchester. Since then, Prof. Awad has published a number of articles that explore a wide range of themes and aspects in the works of Arab writers in diaspora such as cultural translation, identity and multiculturalism. 